B3

J. bio-sci. 14: 73-76, 2006

ISSN 1023-8654

\title{
INFLUENCE OF SOIL MOISTURE ON SOME PHYSIOLOGICAL CHARACTERS AND ROOT AND ALKALOID YIELDS OF RAUVOLFIA SERPENTINA
}

\author{
D Paul, N K Paul * and P Basu \\ Department of Botany, North Bengal University, Raja Rammohanpur, Darjeeling, India \\ * Department of Botany, University of Rajshahi, Rajshahi, Bangladesh
}

\begin{abstract}
Relative leaf water content of the irrigated plants of Rauvolfia serpentina was significantly higher than that of the rainfed plants. Soil moisture effect was found to be significant for chlorophyll $a, b$ and total chlorophyll. Rainfed plants had significantly higher proline and sugar content than the irrigated plants. Main root length, total alkaloid and reserpine contents were unaffected by soil moisture, but air-dried root yield gradually increased with the increase of irrigation frequency.
\end{abstract}

Key words: Irrigation, relative leaf water content, chlorophyll, sugar, root yield, reserpine.

\section{Introduction}

Rauvolfia serpentina grows wild in forests under high rainfall conditions of about 100 to $150 \mathrm{~cm}$ per annum. The natural habitat of the plant suggests that it is grown in partial shaded areas as undergrowth. As a result, plant water deficit usually increases less quickly and photosynthesis proceeds for longer period in shelter. However, little information is available on the irrigation and water requirement of $R$. serpentina as a plantation crop (Sahu 1972, Maheswari et al. 1991).

The objectives of the study were to gain information about the effect of soil moisture on relative leaf water content, some biochemical parameters, root and alkaloid yields of $R$. serpentina.

\section{Materials and Methods}

The experiment was carried out in the experimental field of North Bengal University, Darjeeling, India. The field was prepared after repeated ploughing. A basal dose of urea (80 kg/ha), TSP (50 kg/ha) and MP (40 $\mathrm{kg} / \mathrm{ha}$ ) were added to the field. Uniform and healthy seedlings of $R$. serpentina of 30-40 days old were transplanted in the field on 28 September 1998. A spacing of $30 \mathrm{~cm} \times 30 \mathrm{~cm}$ was followed and there were 3 replications.

Three levels of irrigation treatment were adopted viz., (i) rainfed (lo= no irrigation), (ii) irrigation once in every month $\left(l_{1}\right)$ and (iii) irrigation twice in every month $\left(I_{2}\right)$. On each occasion, $20 \mathrm{~mm}$ of irrigation water were uniformly added over the irrigated plots with sprinklers. Irrigation started from November, 1998 and continued up to May, 1999.

Relative leaf water content (RLWC) was determined from the fully matured leaves. The leaves were collected at $8 \mathrm{am}, 12$ noon and $4 \mathrm{pm}$ and RLWC was determined according to Barrs and Weatherley (1962). Chlorophyll content (Arnon 1949), proline content (Bates et al. 1973) and sugar content (Jayaraman 1975) were estimated at three times, i e, at 120, 180 and 240 days after transplanting (DAT).

\footnotetext{
"To whom all correspondence should be addressed.
} 
After 18 months of planting, plants were dug out in March, 2000 and the roots were separated and washed in the running tap water. The roots were air-dried to a constant weight. Six randomly selected plants from each treatment and replication were used for this purpose. Root samples were analysed for total alkaloid and reserpine contents (Paul 2001).

\section{Results and Discussion}

Relative leaf water content (RLWC) of the irrigated plants $\left(l_{1}\right.$ and $\left.l_{2}\right)$ was significantly higher than that of the rainfed plants ( $\left(l_{0}\right)$ (Table 1). Similar result was reported in wheat by Sarker et al.(1999) and Rahman and Paul (1998), in rape by Raja and Bishnoi (1990) and Kundu and Paul (1996) and in mustard by Begum and Paul (1993).

Table 1. Relative leaf water content (\%) of $R$. serpentina at different times of the day as influenced by soil moisture.

\begin{tabular}{|c|c|c|c|}
\hline \multirow{2}{*}{ Treatment } & \multicolumn{3}{|c|}{ Time } \\
\cline { 2 - 4 } & $8 \mathrm{am}$ & 12 noon & $4 \mathrm{pm}$ \\
\hline $\mathrm{I}_{0}$ & 88.0 & 75.0 & 75.8 \\
\hline $\mathrm{I}_{1}$ & 93.2 & 79.3 & 82.0 \\
\hline $\mathrm{I}_{2}$ & 95.7 & 80.0 & 84.7 \\
\hline LSD 5\% & 3.2 & 2.7 & 4.0 \\
\hline
\end{tabular}

In all the three treatments, RLWC was higher towards the morning, got reduced at noon and again showed some recovery towards the afternoon (Table 1). This behaviour was related to the environmental conditions and is in agreement with earlier reports (Begum and Paul 1993, Mondal and Paul 1996, Sarker et al. 1999).

In the present study, soil moisture effect was found to be significant for chlorophyll $a, b$ and total chlorophyll (Table 2). A reduction of chlorophyll formation due to water stress was also reported by Mondal and Paul (1992), Begum and Paul (1993), Kundu and Paul (1997) and Sarker et al. (1999). However, Saha and Paul (1997) did not find any significant effect of soil moisture on chlorophyll content of wheat.

Table 2. Mean values of chlorophyll content $\left(\mathrm{mg} \mathrm{dm}^{-2}\right)$ of $\mathrm{R}$. serpentina leaf as influenced by soil moisture.

\begin{tabular}{|c|c|c|c|}
\hline Treatment & Chlorophyll a & Chlorophyll b & Total chlorophyll \\
\hline$I_{0}$ & 3.07 & 0.72 & 3.79 \\
\hline $\mathrm{I}_{1}$ & 3.62 & 0.87 & 4.48 \\
\hline $\mathrm{I}_{2}$ & 3.71 & 0.90 & 4.61 \\
\hline LSD 5\% & 0.13 & 0.09 & 0.14 \\
\hline
\end{tabular}

The rainfed plants (lo) had significantly higher proline content than the irrigated plants $\left(l_{1}\right.$ and $\left.I_{2}\right)$ (Table 3 ). Similar result was also reported in wheat (Saha and Paul 1997, Rahman and Paul 1998, Sarker et al.1999), in rape (Paul and Kundu 1991, Kundu and Paul 1997) and in mustard (Begum and Paul 1993). Proline works as a source of energy, carbon and nitrogen and also protects several enzymes against the inactivating effects of heat during water stress (Paleg et al. 1981). Hence possibly proline accumulation under water stress helps the plant to resist drought. 
Table 3. Proline content ( $\mu \mathrm{g} / \mathrm{g}$ fresh weight) of $R$. serpentina leaf as influenced by soil moisture at different stages of growth.

\begin{tabular}{|l|c|c|c|}
\hline \multirow{2}{*}{ Treatment } & \multicolumn{3}{|c|}{ Days after transplanting } \\
\cline { 2 - 4 } & 120 & 180 & 240 \\
\hline $\mathrm{I}_{0}$ & 249 & 265 & 272 \\
\hline $\mathrm{I}_{1}$ & 166 & 170 & 180 \\
\hline $\mathrm{I}_{2}$ & 148 & 174 & 191 \\
\hline LSD 5\% & 24 & 32 & 28 \\
\hline
\end{tabular}

Table 4. Total sugar content ( $\mathrm{mg} / \mathrm{g}$ dry weight) of $R$. serpentina at three growth stages as influenced by soil moisture.

\begin{tabular}{|l|c|c|c|}
\hline \multirow{2}{*}{ Treatment } & \multicolumn{3}{|c|}{ Days after transplanting } \\
\cline { 2 - 4 } & 120 & 180 & 240 \\
\hline $\mathrm{I}_{0}$ & 12.6 & 13.5 & 14.8 \\
\hline $\mathrm{I}_{1}$ & 11.7 & 11.5 & 12.4 \\
\hline $\mathrm{I}_{2}$ & 9.5 & 9.8 & 11.5 \\
\hline LSD 5\% & 1.7 & 2.5 & NS \\
\hline
\end{tabular}

Total sugar content was significantly higher (except at 240 DAT) in the rainfed plants (Table 4). Kundu and Paul (1997) and Sarker et al. (1999) obtained similar results. As the water stress increased at the later stage, the amount of sugar also increased in all the three treatments $\left(l_{0}, l_{1}\right.$ and $\left.l_{2}\right)$, but the amount was much greater in the rain fed plants.

The results of the present study indicate that moisture stress had an inhibitory effect on RLWC and chlorophyll content, but proline and sugar contents of leaves increased markedly as a result of soil dryness. High proline and sugar accumulation of $R$. serpentina in drought conditions might be an adaptation for tolerance of drought, which helps the plant to survive and continue production during the dry season.

Table 5. Effect of soil moisture on root yield and alkaloid content of $R$.. serpentina.

\begin{tabular}{|l|c|c|c|c|}
\hline Treatment & $\begin{array}{c}\text { Main root length } \\
(\mathrm{cm})\end{array}$ & $\begin{array}{c}\text { Air-dried root } \\
\text { weight/plant }(\mathrm{g})\end{array}$ & $\begin{array}{c}\text { Total alkaloid } \\
\text { content }(\%)\end{array}$ & $\begin{array}{c}\text { Reserpine content } \\
(\%)\end{array}$ \\
\hline $\mathrm{l}_{0}$ & 50 & 32 & 1.62 & 0.38 \\
\hline $\mathrm{l}_{1}$ & 52 & 37 & 1.83 & 0.42 \\
\hline $\mathrm{I}_{2}$ & 47 & 44 & 1.74 & 0.40 \\
\hline LSD 5\% & NS & 3 & NS & NS \\
\hline
\end{tabular}

Effects of soil moisture on root yield and alkaloid contents are presented in Table 5. Main root length, total alkaloid and reserpine contents were unaffected by soil moisture, but air-dried root yield increased with the increase of irrigation frequency. 
Little information is available on the irrigation and water requirement of $R$. serpentina as a plantation crop. Sahu (1972) reported that overall growth of $R$. serpentina plantation diminished with increasing water stress, but root growth was less influenced than was shoot growth. Root yield of the crop grown without irrigation was less than the irrigated ones.

The results of the present investigation indicated that better growth of $R$. serpentina is possible in wellwatered condition, which ultimately considered as the basic need for satisfactory root yield. The results also suggest that during the dry season, irrigation of $R$. serpentina once in a month will assure high root yield.

\section{References}

Arnon D I (1949) Copper enzymes in isolated chloroplast polyphenol oxidase in Beta vulgaris. Plant Physiol. 24: 1-15.

Barrs H D and Weatherley P E (1962) A re-examination of the relative turgidity technique for estimating water deficits in leaves. Aust.J.Biol.Sci. 15: 413-428.

Bates L S, Waldren R P and Teare I D (1973) Rapid determination of proline for water stress studies. Plant Soil 39: 205-207.

Begum F A and N K Paul (1993) Influence of soil moisture on growth, water use and yield of mustard (Brassica juncea L.). J. Agron. \& Crop Sci. 170: 136-141.

Jayaraman J (1975) Laboratory Manual in Biochemistry. Wiley Eastern Ltd., New Delhi, p.53.

Kundu P B and N K Paul (1996) Comparative study of water relation in three cultivars of rape seed (Brassica campestris L.) under irrigated and non-irrigated conditions. Bangladesh J. Bot 25: 147-153.

Kundu P B and N K Paul (1997) Effect of water stress on chlorophyll, proline and sugar accumulation in rape seed (Brassica campestris L.). Bangladesh J. Bot. 26: 83-85.

Maheswari S K, O P Sharma, S K Gangrade and K C Trivedi (1991) Irrigation schedule for sarpagandha (Rauvolfia serpentina) in a shallow black soil. Indian J. agric. Sci. 61: 169-171.

Mondal R K and N K Paul (1992) Growth and some physiological characters of mustard under rainfed and irrigated conditions. Bangladesh J. Agri. Res. 17: 29-36.

Paleg L G, T J Douglas, A Van Dall and D B Keech (1981) Proline, betaine and other organic solutes protect enzymes against heat inactivation. Aust. J. Plant Physiol. 8: 107-114.

Paul N K and P B Kundu (1991) Influence of soil moisture on growth, water use and yield of rapeseed (Brassica campestris L.) Proc. Int. Con. PI. Physiol. pp. $35-42$.

Paul D (2001) Pharmacognosy of Rauvolfia serpentina (L.) ex. Kruz. in the ecological condition of Darjeeling district of West Bengal. Unpublished Ph.D. Thesis. North Bengal University, India.

Rahman M S and N K Paul (1998) Effect of soil moisture regimes on physiological characters and yield of wheat cultivars. J. biosci. 6: 5-10.

Raja V and K C Bishnoi (1990) Evapotranspiration, water use efficiency, moisture extraction pattern and plant water relations of rape (Brassica campestris) genotypes in relation to root development under varying irrigation schedules. Expl. Agric. 26: 227-233.

Saha S K and N K Paul (1997) Metabolic activity and grain yield of wheat under well watered and water stress conditions. Bangladesh J. Inds. Sci. Res. 32: 467-468.

Sahu B N (1972) Response of Raovolfia serpentina to irrigation, nitrogen and phosphate application. Indian Forester 18: 312-316.

Sarker A M, M S Rahman and N K Paul (1999) Effect of soil moisture on relative leaf water content, chlorophyll, proline and sugar accumulation in wheat. J. Agron. \& Crop Sci. 183: 225-229. 